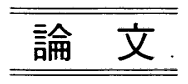

\title{
融雪期における林内放射収支量の 開空率依存性
}

\author{
中 林 宏 典 $^{1)}$, 石 川信 敬 ${ }^{2)}$, 兒玉 裕 ${ }^{22}$
}

\begin{abstract}
要 旨
魚眼レンズで撮影した全天写真をもとに, 林の全天開空率 $(P)$ と太陽経路開空率 $(Q)$ の関係を求め, 林 外で得られた気象要素, 放射量の観測値を用いて, 林内融雪の支配因子である放射収支量を推定する手法 を提示し, 放射収支量の開空率依存性を明らかにした。晴天日の放射収支量は, 全天開空率 $(P)$ の増加と ともに増大するが，Pがおよそ0.8以上では減少することがわかった。これは林内への日射透過量が増大 することよりも，樹冠起源の下向き長波放射量の減少が寄与しているためである. 放射収支量の開空率依 存性は, 日射量の多い晴天日，あるいは積雪表面のアルベドが低く，吸収される日射量の割合が大きいほ ど顕著になる，日射量の少ない量天日やアルベドが高いときには, 放射収支量の開空率依存性は弱く, 森 林状態の違いによる放射収支量の違いは小さくなっている.
\end{abstract}

キーワード：森林，放射収支量，融雪

Key words : forest, net radiation, snowmelt

\section{1. 鍺言}

冬期に積雪として山地流域に蓄えられる水は, 貴重な 水資源となる一方，急激な融雪によっては洪水や地滑り 等の災害要因にもなる．よって積雪流域における融雪量 予測は, 水資源の有効利用や防災の面からも重要な課題 である．融雪は積雪表面における熱収支の結果として決 まることから，流域全体の積雪表面における熱収支を求 めれば，流域内の融雪量を算定できる。しかし森林に覆 われた山地流域において, 熱収支法を用いて融雪量を推 定するには，熱収支に与える森林の影響を明らかにする 必要がある。

融雪に与える森林の影響を扱った研究例として, Kuusisto（1984）は, 森林内では風速が減衰するため, 顕熱, 潜熱伝達量が抑制されることから, 融雪熱量に占 める放射収支量の割合が高くなり，森林内の融雪に対す る支配要因になると述べている．橋本ら（1992）は，落 葉広葉樹林内外において融雪量の比較観測を行い, 林内 における融雪量減少の原因について, 熱収支的に考察し

1）(斯)日本気象協会北海道本部 厂064 札幌市中央区北 4 条西23丁目

2) 北海道大学低温科学研究所 于060 札幌市北区北19条西 8 丁目

ている. 林内外の融雪量は，主として放射収支量に依存 しているため, 両地点の融雪量の差異は, 放射収支量の 差に起因していると結論づけている. Yamazaki and Kondo（1992）は, 森林内の融雪熱量を理論的計算に 基づき推定している．その結果，気温が高い，あるいは 風がないという条件下においては，樹冠を起源とする長 波放射量の影響により，林内の融雪熱量は開地の値を上 回ることを示唆している. よって森林内の放射特性を明 らかにすることは，流域融雪熱収支を考える上で不可欠 であると言える（太田，1992）。

放射収支量は短波放射収支量, 長波放射収支量の和で あるため，森林内の放射特性解明に当たっては，各放射 成分に対する森林の影響を明らかにしなければならない 森林内の短波放射（日射）量に関して，Federer （1971）は, 着葉していない落葉樹林を樹冠部, 及び樹 冠部の 2 層に分け, それぞれの層に抄ける直達日射, 散 乱日射の透過率を求め, 林床に到達する日射量の推定法 を提示している.また, Wilson and Petzold (1973) は, 一様な針葉樹林内の日射量を推定している.しかし 林内の融雪量を定量的に論議するためには, 樹木による 日射の遮蔽効果のみならず, 長波放射量の効果について も議論の対象としなければならない。さらに山地流域に 
は様々な森林が存在しているため, 樹種にとらわれない 放射量推定法の確立が要求される．本論文では，林を定 量的に表す指標として，林床から見た全天に空の占める 割合で定義される開空率を用い, 開空率と各放射量の関 倸を明らかにする。 そして様々な開空率の林について, 林内の放射収支量を林外の観測值から求める手法を提示 し, 融雪期における林内放射収支量の開空率依存性につ いて論じる.

\section{2. 観測の概要}

観測は北海道幌加内町母子里の北大雨龍地方演習林内 実験流域（北緯 $44^{\circ} 23^{\prime}$, 東経 $142^{\circ} 17^{\prime}$ ）で行った（図 1 ）. 流域面積は約 $1.3 \mathrm{~km}^{2}$ であり，海抜高度 $285 \sim 535 \mathrm{~m}$ に位 置する，地表面には笹か滵生し，針広混交の疎林が広がっ ているが，流域下部には比較的密な林が存在する，当流 域は日本でも有数の寒冷多雪地带に属し, 冬期の最低気 温は一 $-30^{\circ} \mathrm{C}$ 以下になることもある。積雪は 12 月から 5 月 にかけて約 6 力月間存在し, 最大積雪深は $2 \mathrm{~m}$ 以上にも なる，融雪期は例年 4 月上旬に始まり，約 1 力月継続す
る.

流域末端から直線距離にして約 $700 \mathrm{~m}$ 離れた平坦な開 地に気象観測露場 $(O)$ を設け, 観測の基準点とし, 気象 要素, 並びに放射量を観測した。なお今後, 気象観測露 場を単に露場と呼ぶ. 森林内の気象要素, 放射量の観測 は，露場の北側に隣接する針葉樹林 (C)で行った（図 1 ). 針葉樹林は樹高約 $10 \mathrm{~m}$ のトウヒ林であり, 東西約 $70 \mathrm{~m}$, 南北約 $20 \mathrm{~m}$ の規模を持つ. 図 2 には,針葉樹林の林床部 から天空方向を撮影した全天写真を示した．針葉樹林は 露場と同一標高の平坦地に位置しており, 地形的な条件 は等しいため, 両地点で得られた放射量の差異は, 森林 の影響によると言える.

観測期間は 4 月の融雪期を中心とする約 1 力月間であ ク，1994，1995年の 2 年にわたって行った。各観測地点 において連続測定を行った項目を表 1 に示す. 気温, 相 対湿度は, それぞれサーミスター温度計, 静電容量式湿 度計を用い, 強制通風して測定した. 全天日射量, 反射 日射量は全天日射計，大気放射量は赤外放射計，放射収 支量は放射収支計を用いてそれぞれ測定した．積雪表面

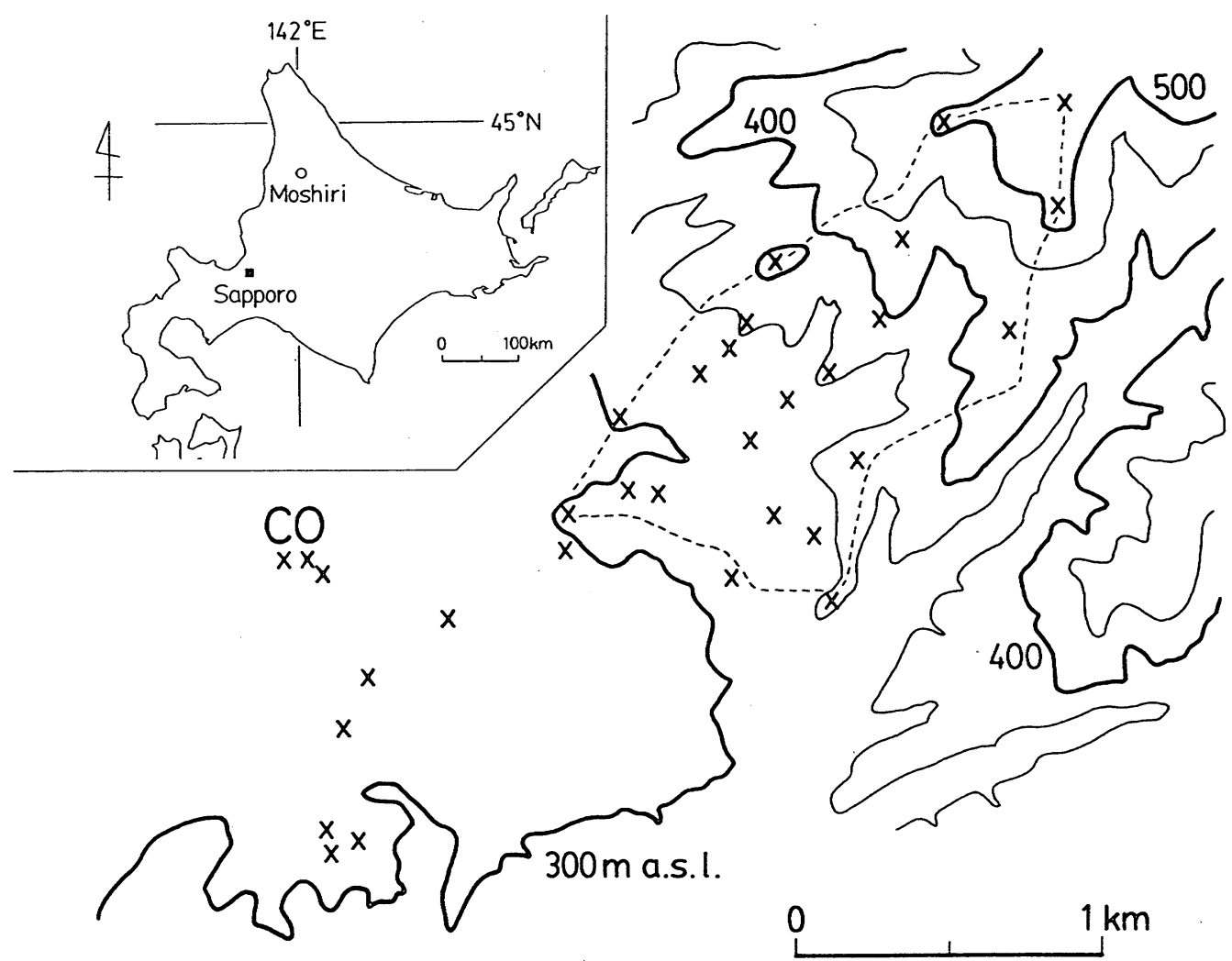

図 1 観測地点 (北海道幌加内町母子里、 0 : 気象観測露場、 $\mathrm{C}$ : 針葉樹林, $\times$ : 全天写真撮影地点). 破線は流域境界を表す 


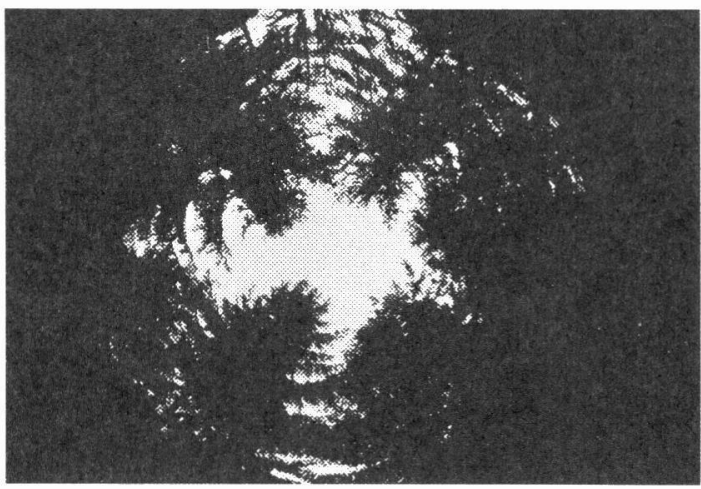

図 2 針葉樹林の全天魚眼写真

温度の測定には赤外放射温度計を用いた，各要素とも 30 秒毎に測定し，30分平均值をデータロガーに収録するこ とを基本とするが，年度，地点によって収録值にばらつ きがあるため, 解析には各要素の 1 時間平均值を用いた。 天気状況，雲量は，1日2回，09時と17時に露場で目視 観測した。母子里の融雪期における気象状態については, 中林ら（1994）を参照されたい.

林の開空率を求めるため, 露場, 針葉樹林, 落葉樹林, 及び混交林を含む流域内外 32 地点（図 1, ×地点）にお いて，魚眼レンズ (Fisheye Nikkor $8 \mathrm{~mm}$ F2.8S) を用いて計47枚の全天写真を撮影した。カメラは三脚に よって，樹木間のほぼ中心の積雪表面上約 $60 \mathrm{~cm}$ に設置 し，水準器を用いてレンズが鉛直上向きになるように， さらに方位磁針により,すべての写真が同一方位で撮影 されるように調節した。なお落葉樹は，観測期間中の 5 月中旬までは全く着葉していない状態である。

林の放射に対する影響は，放射の種類によって異なる。 直達日射は太陽の方向のみが開空していれば遮蔽されな いが，散乱日射，大気放射は全天方向の状況が影響する。 そこで本論文では, 全天写真内に占める空の面積の割合 を全天開空率； $P$ ，母子里における 4 月 1 日と 4 月30日 の太陽経路を表す弧, 及び両日の09時, 15時の太陽位置 をそれぞれ結んだ直線で囲まれる領域に占める空の割合 を太陽経路開空率；Qとした（図 3 )。ここで太陽経路 開空率は直達日射の透過率を, 全天開空率は散乱日射と 大気放射の透過率を想定している。太陽経路開空率を日 の出時刻から求めず，09時から15時としたのは，太陽経 路の障害物として，地形的影響を除いた樹木の影響のみ を考虑するためであり，さらにこの時間帯の日射量は， 1 日の日射総量の $70 \%$ 以上を占めることから，日射によ る融雪を議論する上で重要な時間帯と判断したためであ る. 画像解析にはKONA system PIP-3000を用いた。
表 1 気象要素, 放射量の連続観測項目

( 0 : 気象観測露場， C : 針葉樹林)

\begin{tabular}{|l|l|l|l|l|l|l|l|}
\hline & 日 射 & 反射 & 赤外放射 & 放射收支 & 表面温度 & 気 温 & 湿 度 \\
\hline 1994 & O, C & O & O, C & O, C & O & O, C & O, C \\
\hline 1995 & O, C & O, C & O & O, C & O & O & O \\
\hline
\end{tabular}

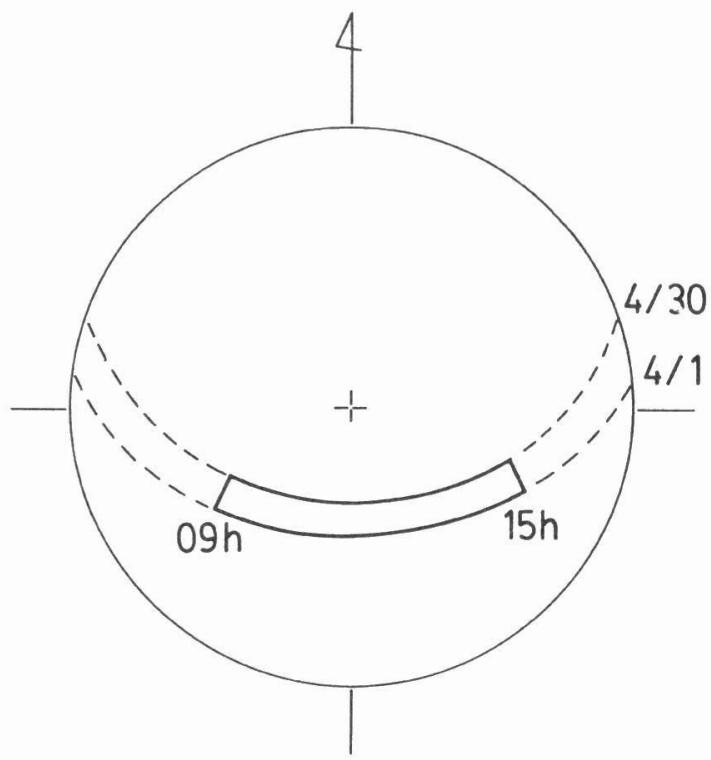

図 3 全天写真模式図. 円は全天, 破線は太陽経路を表 L, 円内に占める空の割合を全天開空率 $(\mathrm{P}), 4$ 月 1 日，30日の太陽経路と，各日の09時，15時に おける太陽経路で囲まれる領域内に空のに占める 割合を太陽経路開空率 $(\mathrm{Q})$ とする.

なお画像処理を容易にするため, 撮影した写真はコピー を撮って白黒に2 值化し, 解析にはコピーを用いた。

森林内の放射収支量は次式のように表される。

$$
\begin{aligned}
N R_{f} & =\left(1-\alpha_{\mathrm{f}}\right) S R_{f}+\varepsilon L D_{f}-\varepsilon \sigma S T_{f}{ }^{4} \\
& =S W R B_{\mathrm{f}}+\mathrm{LWRB}_{\mathrm{f}} \cdots \ldots \ldots \ldots \ldots \ldots \ldots \ldots \ldots \ldots \ldots
\end{aligned}
$$

ここに $\alpha_{f}$ は積雪表面アルベド, SR $R_{f}$ は日射量, $L D_{f}$ は 下向き長波放射量, $\varepsilon$ は積雪の射出率, $\sigma$ は StefanBoltzman 定数, $S T_{f}$ は積雪表面温度, $S W R B_{f}$, $L W R B_{f}$ は, それぞれ短波放射収支量, 長波放射収支量 を表す。次章では, 全天開空率と太陽経路開空率の関係, 及び森林内の日射量, アルベド, 長波放射量の決定法に ついて述べる。 そして林外の実測值から林内の放射収支 量の開空率依存性について議論を進める. 


\section{3. 観測結果}

\section{1 全天開空率と太陽経路開空率の関係}

図 4 には, 全天開空率 $P$ と太陽経路開空率 $Q$ の関係 について，図 1 の×地点で撮影したすべての写真から得

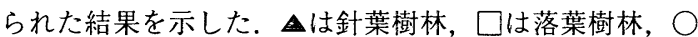
は混交林についての関係を表す。太陽経路開空率は，全

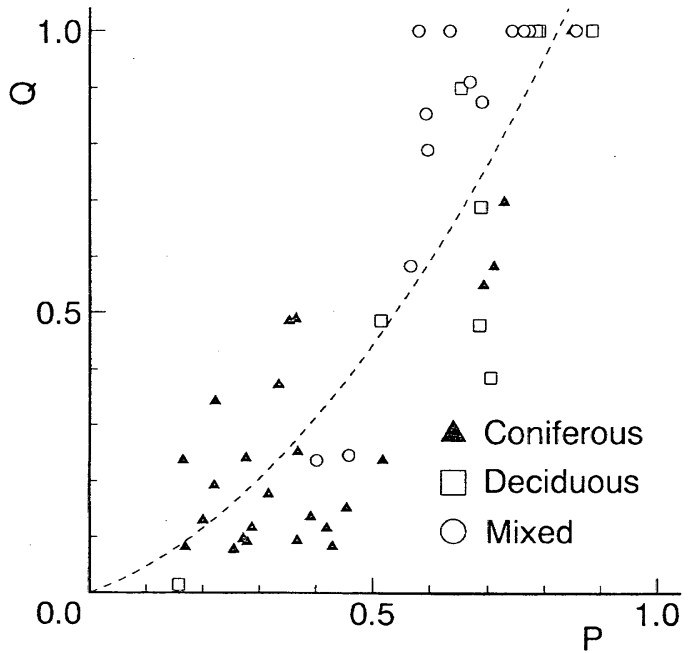

図 4 全天写真解析から得られた全天開空率 $(P)$ ，太 陽経路開空率 $(Q)$ の関係

天開空率が増大するほど全般的に大きくなっている．特 に全天開空率が 0.8 以上の林における太陽経路開空率は, ほぼ 1.0 になっている. 針葉樹林, 落葉樹林, 混交林そ れぞれについて $P$ と $Q$ の関係を求めたところ，樹種に よる特徵的な違いは認められなかった。そこで現段階で は樹種の違いは考慮せず， $(P, Q)=(0,0)$ を通る回帰 式から全天開空率と太陽経路開空率の関係を求めた。最 小自乗法により，QはPの 2 次式として良好に表現さ れた（(2)式, 図 4 中の破線).

$$
Q=0.374 P+1.025 P^{2} \text { （相関係数 } r=0.865 ）
$$

ただし $Q \leqq 1$ である.式(2)により，任意の林について， 全天開空率 $P$ から太陽経路開空率 $Q$ ，すなわち直達日 射透過率が得られることになる。また観測期間中，融雪 に伴う雪面低下によって，樹木が相対的に高くなり，同 一地点における開空率の低下が憂慮される。しかし1994 年の融雪期間中, 約 10 日毎に 3 回撮影を行った結果，同 一地点の開空率には系統的な経時変化は認められたかっ た。すなわち融雪期の約 1 力月間，開空率は一定である と言える.

\section{2 日射量}

全天日射量 $\left(S R_{0}\right)$ は，太陽から直接地表に到達する 直達日射量 $\left(S R_{D}\right)$ と, 大気や雲などに散乱されて到達 する散乱日射 $\left(S R_{F}\right)$ の和である．林の直達日射，散乱

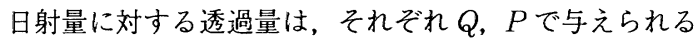
とすると，林内の日射量 $\left(S R_{f}\right)$ は，次式で表される.

$$
S R_{f}=Q \cdot S R_{D}+P \cdot S R_{F}
$$

式(3)から林内の日射量を求めるには，林の $P, Q に$ 加 え, 直達日射量, 散乱日射量をそれぞれ求めなければな らない. 式(4)〜式(6)は, 長野ら（1986）による日射量 の計算式である.

$$
\begin{aligned}
& S R_{o}=S R_{D}+S R_{F} \\
& S R_{D}=I t^{1 / \sin (E L)} \sin (E L) \\
& S R_{F}=\frac{1}{2} I \sin (E L) \frac{1-t^{1 / \sin (E L)}}{1-1.41 \ln (t)}
\end{aligned}
$$

ここにIは太陽定数，EL は太陽高度， $t$ は大気透過率 である。これらの式より, 太陽高度, 及び大気透過率に よって, 全天日射量に占める直達日射量, 散乱日射量の 割合が変化することがわかる．図 5 には，1994年 4 月の 母子里における大気圈外日射量と，露場で観測した全天 日射量の関係を 1 時間平均値について示した。大気圈外 日射量は，式(5)より大気透過率 $t$ を 1 として求まる。 図 5 の中の 2 本の曲線は, それぞれ大気透過率 $t$ を 0.75 ,

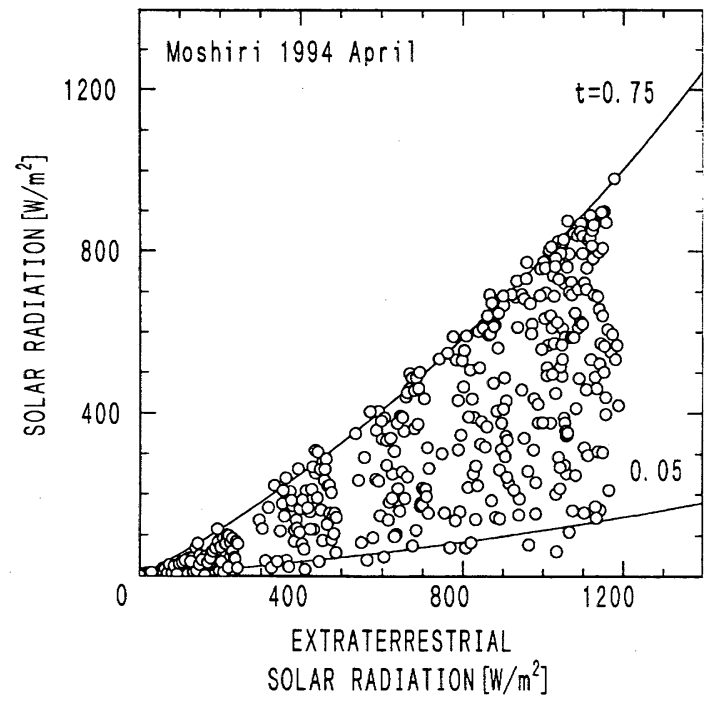

図 5 母子里における1994年 4 月の大気圏外日射量と露 場の日射量. 実線は, 長野ら（1986）に基づく大 気透過率 $t=0.75,0.05$ における計算日射量 
0.05としたときの全天日射量の計算值であるが，それぞ れ母子里の快晴日，量天日に実測された日射量にほぼ等 しく, その他の実測值は両曲線の間に収まっている。そ こで本論文では，露場で実測した全天日射量を再現する のに最適な大気透過率から，その時間における直達日射 量の割合を求め, 露場の全天日射量を直達日射量, 散乱 日射量に分離した。

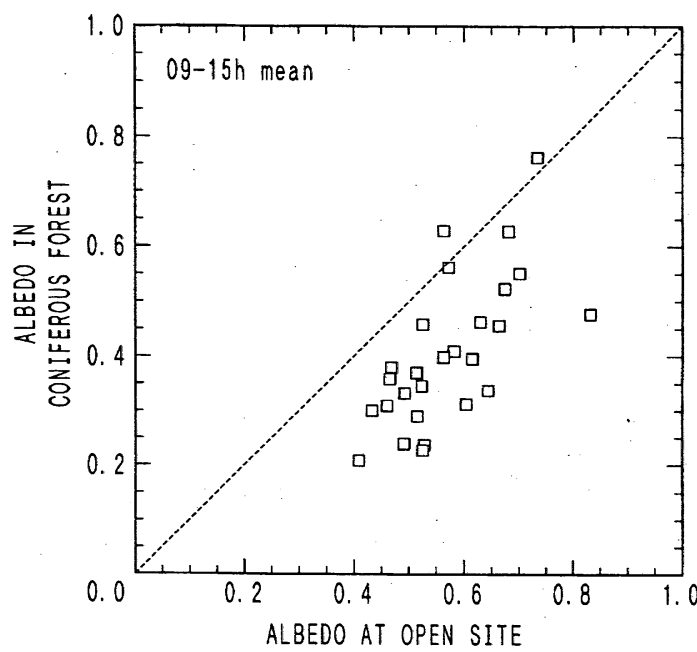

図 6 1995年融雪期における露場, 針葉樹林内のアルベ ド $(09--15 \mathrm{~h}$ 平均値 $)$

\section{3 アルベト}

図 6 は，1995年に実測した露場，針葉樹林内における 09-15h平均のアルベドを比較したものである。露場の 日射量, 反射量は, どちらも積雪表面上 $120 \mathrm{~cm}$ で測定 した．林内の全天日射量は積雪表面上 $20 \mathrm{~cm}$ で测定し， 反射日射量は雪面上で $150 \mathrm{~cm}$ で測定した。林内のアル ベドは，露場に比べて 0.15 程度低くなっている。この 原因として，林内の反射日射計の視野内に，積雪に比べ てアルベドの低い樹木部分が入っていることが考えられ る. 過去の研究から林床雪表面アルベドは, 開地の $95 \%$ (太田，1992），開地の值にほぼ等しい（小池ら，1995） という結果が得られている。 そこで本研究では，林内の 積雪表面アルベドとして露場の值を代用することにする．

\section{4 長波放射覺}

Male and Granger（1981）によると，林内の下向 き長波放射量 $\left(L D_{f}\right)$ は, 全天開空率 $P$, 及び絶対温度 で表した林内の気温 $\left(A T_{f}\right)$ を用いて，次式のように表 される.

$$
L D_{f}=P \cdot L D_{o}+(1-P) \sigma A T_{f}^{4}
$$

ここにLD。は林外の下向き長波放射量（大気放射量）, $\sigma$ はStefan-Boltzman 定数である. 図 7 は, 1992年 4 月から 6 月において，針葉樹林内，及び落葉樹林内で実 測した下向き長波放射量と，式(7)による推定值を比較 したものである(中林ら，1993）。針葉樹林内， は落葉樹林内の値を示す。落葉樹林の全天開空率は， 5

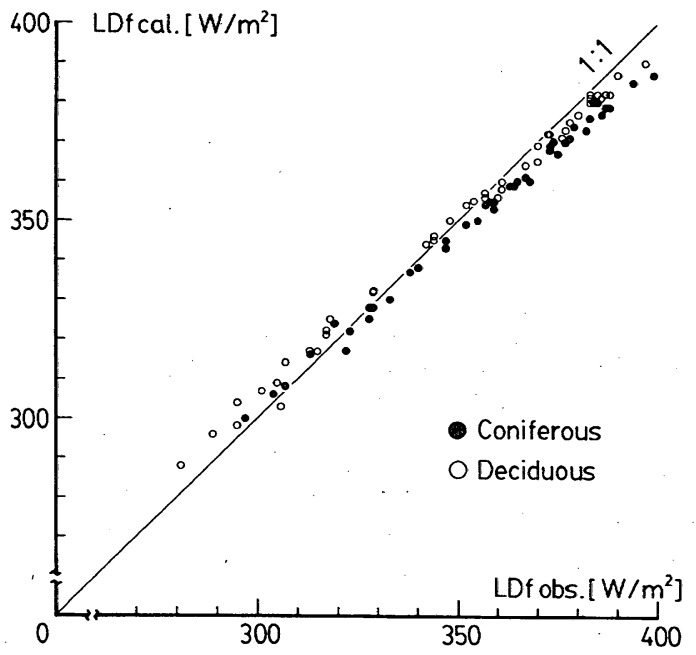

図 7 針葉樹林内, 落葉樹林内の下向き長波放射量（実 測值, 推定值の比較)

月から 6 月にかけての着葉により，0.78から 0.22 まで変 化しているが, 式(7)によって, 樹種, 並びに開空率の 異なる林内の実測值は再現されている．よって任意の林 における下向き長波放射量は, 式(7) から推定可能であ ると言える。なお観測值と実測值の関係には，1：1か らの系統的なずれが認められるが，この原因については 明らかではない。

上向き長波放射量は, 積雪表面温度の黒体放射量と仮 定した．表面温度の日変化傾向は，概ね気温に支配され ており, 露場, 針葉樹林内の気温は, 日最高, 最低值を 含めて，ほぼ等しいという結果が得られている。そこで, 露場における気温と表面温度の関係が林内においても成 り立つとして，1994年観測期間中に露場で得られた気温 との関係式（式(8)）により, 林内の積雪表面温度を推 定した。

$$
\begin{array}{rlr}
S T_{f} & =-1.18+1.08 A T_{f} & \left(A T_{f} \leqq 1.09^{\circ} \mathrm{C}\right) \\
& =0.0 &
\end{array}
$$

しかし表面温度は気温の他にも, 風速, 水蒸気量, 大気 放射量に依存しており（田口ら，1994），放射環境の異 なる林内において, 露場で得られた気温と表面温度の関 
係式を用いるのは適切であるとは言えない．林床積雪表 面温度の取り扱いは，今後検討を要する課題である.

\section{5 実測值との比較}

図 8 には，針葉樹林内の日平均放射収支量の実測值 (実線) と,これまで述べてきた方法による推定值（破 線）を示した。針葉樹林の全天開空率 $(P)$ ，太陽経路 開空率 $(Q)$ は，写真解析から，それぞれ $P=0.23 ， Q$ $=0.14$ が得られている．検証期間は1994年の融雪期， 3

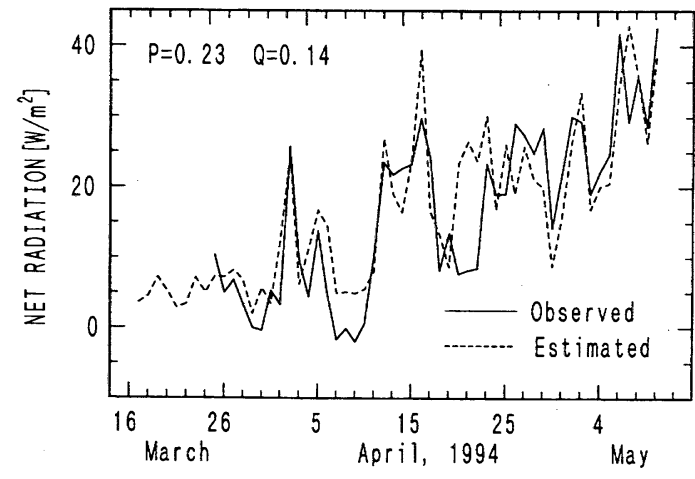

図 8 針葉樹林内における放射収支量の実測値と推定値

月17日から 5 月11日である。推定值は概ね実測值を再現 しており，推定値の標準誤差は $6.6 \mathrm{Wm}^{-2}$ である.

図 9 は, 露場の気象デー夕から推定した1994年 4 月 15 日における全天開空率 $(P)$ と短波放射収支量 $\left(S W R B_{f}\right)$ ，長波放射収支量 $\left(L W R B_{f}\right)$, 及び放射収支

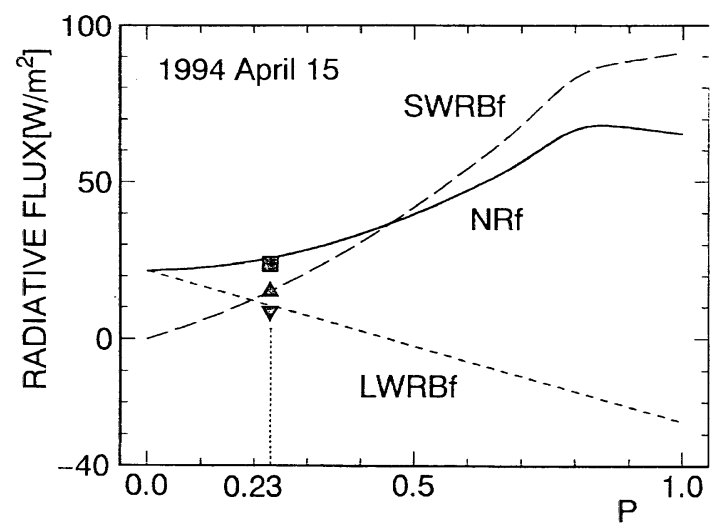

図 9 1994年 4 月15日に扔ける全天開空率 $(P)$ と短波 放射収支量 $\left(S W R B_{f}\right)$, 長波放射収支量 $\left(L W R B_{f}\right)$, 並びに放射収支量 $\left(N R_{f}\right)$ の関係。針葉樹林 $(P$

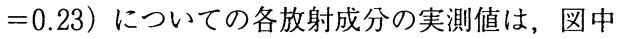
に記号で示した（短波放射収支量， $\boldsymbol{\nabla}$ : 長波 放射収支量, 圈: 放射収支量)。
量 $\left(N R_{f}\right)$ の関係を表す．短波放射収支量は，日射量の 推定值 $\left(S R_{f}\right)$ に $1-\alpha_{f}$ を乗じて求めた。 長波放射収 支量は, 下向き長波放射量 $\left(L D_{f}\right)$ から積雪表面温度の 黒体放射量 $\left(\sigma S T_{f}{ }^{4}\right)$ を減じて求めた。なお針葉樹林 $(P=0.23)$ における各放射成分の実測值は, 図中に記 号で示した（ $\Delta$ : 短波放射収支量, $\nabla$ : 長波放射収支量, 国 : 放射収支量)。短波放射収支量は全天開空率 $P$ の増 加に伴って増大しているが，P 0.8以上では増大が鈍 くなっている。，一方，長波放射収支量は，Pの増加に対 して減少する傾向にある。.以上の結果, 放射収支量は全 天開空率が 0.8 以下の領域では, $P$ の増大に伴い指数関 数的に増大しているが, $\mathrm{P} \sim 0.8$ に極大を持ち，それ以 上の $P$ では減少するという結果が得られた。次章では, 放射収支量の開空率依存性を決定づけている要因につい て議論を進める。

\section{4. 考察}

\section{1 入射放射量の開空率依存性}

図10は，1994年の観測期間中における晴天日，量天日 の全天開空率 $P$ と, 露場の日射量を分離して求めた直 達日射量 $\left(S R_{D}\right)$, 並びに散乱日射量 $\left(\mathrm{SR}_{\mathrm{F}}\right)$ の関倸を 表す。晴天日，是天日の区分には晴天指数 $(C I)$ を用 いた．晴天指数とは大気圈外日射量に対する露場の全天 日射量の比であり，1994年の観測期間中，母子里の晴天 指数は 0.14 から 0.66 であった。ここでは日平均晴天指数

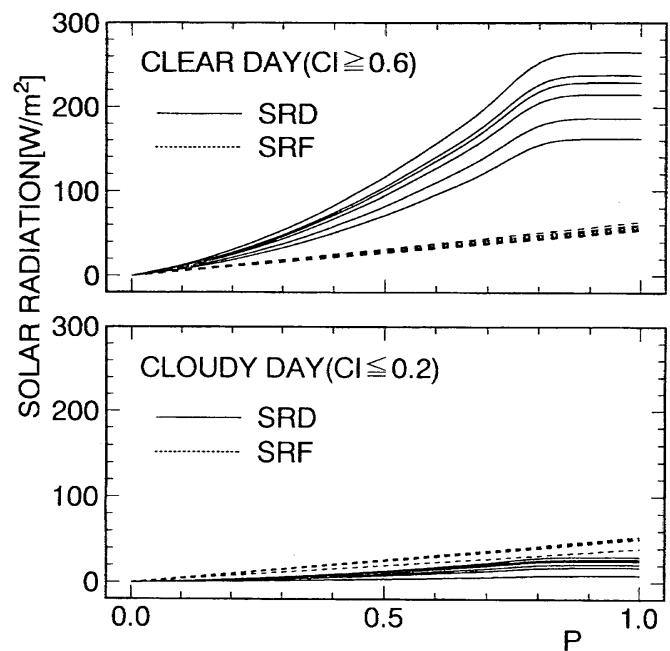

図10 晴天日, 量天日における全天開空率 $(P)$ と直達 日射量 $(S R D)$ ，並びに散乱日射量 $(S R F)$ の 関係. 晴天日, 曇天日の区別は, 晴天指数 $(C I)$ に基づき，1994年の観測期間中， $C I \geqq 0.6$ を晴天 日， $C I \leqq 0.2$ を暴天日とした。 
が0.6以上を晴天日， 0.2 以下の日を是天日とし，各 6 日 間の推定結果を示した：晴天日は全天日射量に占める直 達日射量の割合が高く，全天日射量は直達日射量で決定 されていると言える。しかし全天開空率 $P$ が 0.8 以上の 領域では, 太陽経路開空率 $Q$ が 1 で一定となるため (式(2)），Pが増加しても直達日射量は一定である。一 方，散乱日射量は全天開空率に比例して増大する．是天 日は散乱日射量の割合が高く，全天日射量は散乱日射量 に依存するところが大きい．しかし晴天日に比べて日射 量が小さいため, 開空率の変化に伴う全天日射量の変化 は小さい.

図11には，全天開空率 $P$ と式(7)から推定した下向き 長波放射量の関係について，図10と同一の晴天日，量天 日について示した．開空率の増加は林内へ透過する大気 放射量を増大させる一方，樹冠起源の長波放射量を減少 させる(式(7))。晴天日の長波放射量は曇天日に比べて 全体的に少ない。また長波放射量は，全天開空率の増大 に対して滅少する傾向にあるが，減少の度合いは量天日 に比べて晴天日に顕著である，すなわち，大気放射量の 少ない晴天日には，林内の長波放射量に対する樹冠起源 の長波放射量の影響が，より顕著に現れると言える。

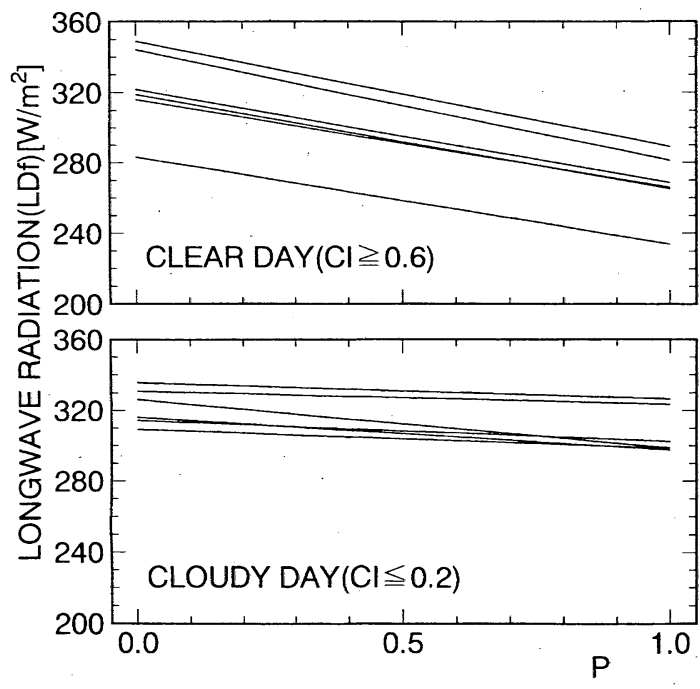

図11 晴天日，曇天日における全天開空率（P） と下向 き長波放射量（式(7)による計算值）の関係．晴天 日，量天日の区分は図10に同じく晴天指数によっ た。

\section{2 林内放射収支置の天候依存性}

図12には，全天開空率 $\mathrm{P}$ と放射収支量の関係を示した。 実線，破線は，それぞれ1994年 4 月23日，同年 4 月24日 における日平均放射収支量の推定值を示す．各日の晴天
指数 CIは，それぞれ $0.52 ， 0.29$ であり，晴天指数を除 いて, 日平均気温 $\left(そ れ そ ゙ れ+1.6{ }^{\circ} \mathrm{C},+2.4^{\circ} \mathrm{C}\right)$, アル ベド $(0.51 ， 0.53)$ などの条件はほぼ等しい，放射収支 量の全天開空率依存性は, 晴天指数が大きいほど顕著で あるが，P〜0.8以上の領域では増大が鈍くなっている. これは主として直達日射量の透過量を反映しているため であり，晴天日の林内放射収支量は，全天開空率よりも

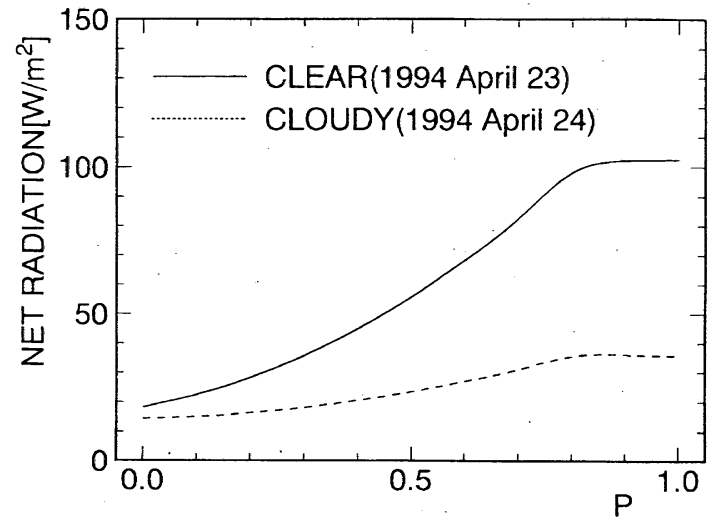

図12 全天開空率 $(P)$ と放射収支量の関係。実線は 1994年 4 月23日（CI=0.52），破線は同年 4 月 24 日 $(C I=0.29)$ の推定結果.

太陽経路開空率に大きく依存していると言える。さらに 林内の長波放射収支量に対しては，樹冠起源の長波放射 量の影響が顕著になるため，放射収支量の全天開空率依 存性が強調される。

晴天指数の小さい日は，それが大きい日に比べて放射 収支量の開空率依存性は弱く，林内外の放射収支量の差 が小さくなっている．この原因として，量天日は日射量 が少ないことから，林の日射遮蔽効果が顕著に現れず， さらに樹冠を起源とする長波放射量の寄与が弱くなって いることも挙げられる，次節では，林内放射収支量の積 雪表面アルベド依存性について考察する.

\section{3 林内放射収支量のアルベド依存性}

図13は，積雪表面のアルベド（ $\left.\alpha_{\mathrm{f}}\right)$ をパラメータとし たときの全天開空率 $P$ と放射収支量の関係を表す，図 1 3 では, 1994年 4 月 15 日（晴天指数 $C I=0.47 ）$ の気象要 素，放射量の実測值を用い， $\alpha_{f}=0.4 ， 0.6 ， 0.8$ につい て計算した結果を示した。放射収支量の開空率依存性は,

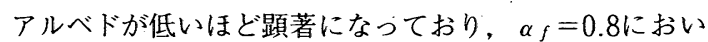
ては，開空率が大きくなっても放射熱収支量はほとんど 変化していない．アルベドが高いとき，林床に到達する 日射量が増大しても，吸収日射量の増大は小さい。しか し下向き長波放射量は開空率が増大すれば減少するため, 


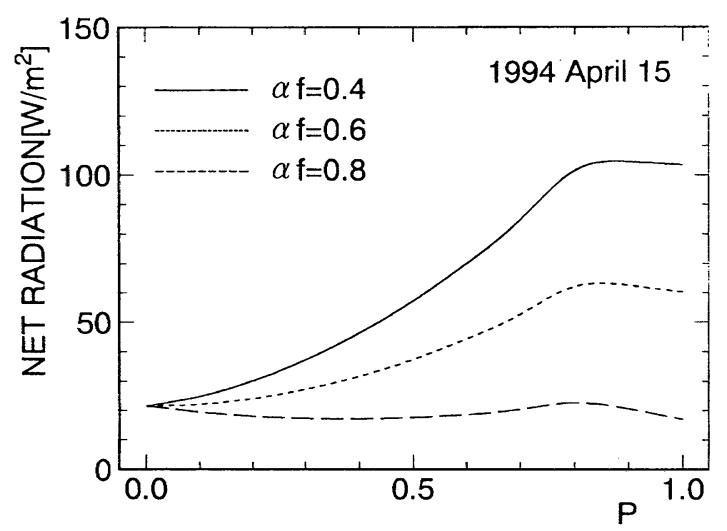

図13 全天開空率 $(P)$ と放射収支量の関係. 1994年 4 月15日 $(C I=0.47)$ について, 林床積雪表面アルベ ド $\left(\alpha_{f}\right)$ をパラメータとする.

長波放射収支量は減少する，全天開空率に対して放射収 支量が一定であることは，開空率増大に伴う短波放射収 支量の増大量と, 長波放射収支量の減少量が釣り合って いるためである．0.8程度の積雪表面アルベドは，融雪 期以前の冬期から融雪期初期に観測されるが, この時点 では，林内外の放射収支量は大差ないが，その後融雪の 進行に伴ってアルベドが徐々に低下し，林内外の放射収 支量の差が大きくなった結果, 林内外の融雪量には差が 生ずるようになると推察される.

\section{5. まとめ}

全天写真から得られた全天開空率 $(P)$ ，太陽経路開 空率 $(Q)$, 並びに林外で得られた気象要素, 放射量の 観測值を用い，融雪期における林内の放射収支量を推定 する手法を提示し，放射収支量の開空率依存性を明らか にした，晴天日の放射収支量は，全天開空率 $P$ の增加 とともに增大するが， $P \sim 0.8$ を境として，それ以上で は減少することがわかった。これは林内への透過日射量 が増大することよりも，樹冠起源の下向き長波放射量の 減少が大きく寄与しているためである．放射収支量の開 空率依存性は, 日射量の多い晴天日，あるいは積雪表面 のアルベドが低く，吸収される日射量の割合が大きいほ ど顕著になり，日射量の少ない曇天日やアルベドが高い ときには，放射収支量の開空率依存性は弱く，森林状態 の違いによる放射収支量の違いは小さいことがわかった。

\section{謝辞}

観測を行うに当たり, 北大雨龍地方演習林の皆様には,
観測期間中数多くの協力を頂きました。本研究をまとめ るに際し, 北海道大学低温科学研究所融雪科学部門の小 林大二教授, 石井吉之助手には, 有益な助言を頂きまし た。ここに記して感謝の意を表します。なお本研究経費 の一部は, 文部省科学研究費 (課題番号 06455002, 研 究代表者・石川信敬）から支出された.

\section{文献}

Federer, C. A., 1971 : Solar radiation absorption by leafless hardwood forest. Agric. Meteorol., 9, 320.

橋本哲, 太田岳史, 石橋秀弘, 1992 : 落葉樹林が表層融 雪量に与える影響に関する熱収支的検討．雪水， 54 , 131-143.

小池正子, 小池俊雄, 早川典生, 下垣久, 1995 : 森林条 件の違いによる雪面熱収支特性に関する比較研究. 水文・水資源学会誌，8，389-398.

Kuusisto, E., 1984 : Snow accumulation and snowmelt in Finland. Vesihallitus-National Board of Waters, Finland, pp.149.

Male, D. H. and Granger R. J., 1981 : Snow surface energy exchange. Water Resour. Res., 17, 609627.

中林宏典, 石川信敬, 兒玉裕二, 1993 : 融雪期における 林内放射収支量の推定. 低温科学, 物理篇, 52, 1524 .

中林宏典，新美和造，谷口健志郎 1994 ：母子里におけ る融雪期の地上気象観測 $-1991 \sim 1994$ 年 - . 低温科 学, 物理篇, 53, 資料集, 21-32.

長野敏英, 清野害, 佐瀬勘紀, 塩沢昌，石田朋彦，青木 正敏, 内島立郎, 真木太一, 大政謙次, 岡田益己, 藤田憲次, 皆川秀雄, 1986 : 農業気象・環境学. 朝 倉書店, pp191.

太田岳史 1992 : 森林内外における積雪面上の純放射量 の推定と表層融雪量. 水文·水資源学会誌，5，1926.

田口文明, 山崎剛, 近藤純正 1994 : 積雪表面温度の推 定について. 雪水, 56, 11-18.

Yamazaki, T. and Kondo J., 1992 : The Snowmelt and heat balance in snow-covered forested area. J. Appl. Meteorol., 31, 1322-1327.

Wilson, R. G. and Petzold D. E., 1973 : A solar radiation model for sub-arctic woodlands. J. Appl. Meteorol., 12, 1259-1266. 
Radiative characteristics in forest during snowmelt season

\author{
Hironori NaKabayashi" ${ }^{1)}$, Nobuyoshi IshiKawa ${ }^{2)}$ and Yuji Kodama ${ }^{2)}$ \\ 1) Japan Weather Association, north 4 west 43, Sapporo 064, Japan \\ 2) Institute of Low Temperature Science, Hokkaido University, \\ north 19 west 8, Sapporo 060, Japan
}

\begin{abstract}
In analyzing all-sky photographs, a method to estimate net radiation in forest during snowmelt season is proposed. The relations between sky-view factor and net radiation at the forest bed in various weather conditions are investigated. In clear day, net radiation is proportional to sky-view factor up to about 0.8 , but above that value, the net radiation decreases with increasing sky-view factor. The larger the sky-view factor is, the more solar radiation and the less downward long-wave radiation from forest canopy is received at the forest floor. Net radiation at the forest floor is more dependent on the sky-view factor when clear sky and low albedo of the forest floor, and less dependent when cloudy sky and high albedo of the forest floor.
\end{abstract}

（1995年 9 月 1 日受付，1995年10月23日改稿受付，1995年12月 9 日受理，討論期限1996年11月10日） 